\title{
Framing the tax and health nexus: a neglected aspect of public health concern
}

\author{
DAVID MCCOY* \\ Centre for Primary Care and Public Health, Queen Mary University of London, London, UK \\ SIMUKAI CHIGUDU \\ Oxford Department of International Development, University of Oxford, Oxford, UK \\ TAAVI TILLMANN \\ Department of Epidemiology and Public Health, University College London, London, UK
}

\begin{abstract}
Previous studies have described various associations between tax policy and health. Here we propose a unifying conceptual framework of 'Five R's' to stimulate awareness about the importance of tax to health improvement. First, tax can improve representation and democratic accountability, and help make governments more responsive to the needs of its citizens. Second, tax can create a revenue stream for a universal pool of public finance for health care and other public services. Third, progressive taxation when combined with appropriate public spending can help redistribute wealth and income and mitigate social and health inequalities. Fourth, the re-pricing of harmful products (e.g. tobacco, alcohol and unhealthy food) can help reduce their consumption. Fifth, taxation provides a route by which certain harmful industries can be regulated. The paper also discusses the barriers that hinder the full potential for taxation to be used to improve health, including: weak tax administrations, large 'shadow economies', international trade liberalisation, tax avoidance, transfer pricing by transnational corporations and banking secrecy. We suggest that a greater awareness of the manifold associations between tax and health will encourage health practitioners to actively promote fairer and better taxation, thereby helping to improve health and reduce health inequalities.
\end{abstract}

Submitted June 2016; revised September 2016; accepted November 2016

\section{Introduction}

Public debate about taxation is usually focussed on the impacts of tax on household income and the extent to which it is progressive or regressive. There may also be some focus on different types of tax (Box 1), and their relative merits.

\footnotetext{
*Correspondence to: Dr David McCoy, Centre for Primary Care and Public Health, Blizard Institute, Barts and The London School of Medicine and Dentistry, 4 Newark Street, London E1 2AT, UK. Email: d.mccoy@qmul.ac.uk
} 
Box 1.

Tax is applied in different forms, ranging from direct taxes on personal and corporate income and wealth, through to indirect taxes on retail sales, consumption of goods and services, trade and the discharge of pollutants, and mandatory social security contributions. Tax exemptions and subsidies are also aspects of tax policy

In mainstream economics, the primary concern is often the effect of tax policy on fiscal stability, private investment and other aspects of macroeconomic performance. Social scientists, on the other hand, are more likely to emphasise the social and political dimensions of tax (Moore, 2007; Bräutigam, 2008).

This paper examines the general policy domain of taxation through the lens of public health with the purpose of describing its relevance to several health-related challenges. It aims to encourage the international health community to take greater interest in the formulation of tax policy nationally and globally. In so doing, it intersects with the analysis of Riku Elovainio and David B. Evans whose contribution to this special issue, 'Raising domestic money for health: prospects for low and middle income countries', examines the potential of 46 low- and middle-income countries (LMIC) to substantially increase their health expenditures from domestic sources. Elovainio and Evans argue that measures such as redistributing existing tax revenues, expanding the tax base by formalising economies, increasing tax on natural resources and implementing 'sin taxes' (taxes on harmful consumptive products like tobacco) can increase domestic funding for health. This paper both reinforces this argument and expands it conceptually by offering a framework for thinking systematically about the multi-faceted interrelationships between tax and health. There is thus much overlap between the two papers, but it is argued that this overlap is complementary and underscores the need for further research and policy measures at the nexus of tax and health.

The paper first provides a brief overview of five different effects of tax and how they impact on health. The five effects, described as a set of five 'Rs' to facilitate recall, are representation, revenue, redistribution, re-pricing and regulation. It then discusses some of the difficulties and barriers that countries face in harnessing the benefits of tax (in their different forms), with an emphasis on low-income countries (LICs). Finally, the paper highlights some general policy recommendations and avenues for further research.

\section{The effects of tax}

\section{Representation}

Representation refers to the role that taxes can potentially play in strengthening democracy and giving citizens a 'claim' over government. By contributing to 
public revenue generation, tax systems provide a mandate for households and communities to hold governments accountable and make claims on the state for the provision of various services and goods, including health services. Furthermore, tax provides a source for public finance which allows governments to pay for equitable and universal health care, an important issue given the inequities and market failures inherent in private financing for health care.

In describing the transition from domain states (in which government activities were funded from surpluses derived from the monarchy's own properties) to tax states (in which the state earned its revenue by taxing its citizens), Prichard (2010) describes the emergence of three inter-connected sets of processes by which taxation facilitates a 'political contract' between states and society.

The first set is described as common interest processes that arise from governments becoming dependent on tax revenue and thereby incentivised to promote economic prosperity amongst its citizens. The second set is described as accountability and responsiveness processes that arise from citizens making claims of government and engaging in political decision-making as a result of being a tax-payer. This is perhaps best illustrated by the famed 'Boston Tea Party' incident of 1773 when American settlers rebelled against unjust taxes imposed by the British after which the slogan 'no tax without representation' was coined and used as a rallying cry during the American war of independence. The third set is state apparatus processes which consist of the development of bureaucratic systems for administering tax, including the creation of population-based data collecting systems, that in turn facilitates more effective public sector planning and resource allocation.

Tax systems also affect the governance of society by influencing the social and political relationship between different population groups within a society, including groups defined by wealth, geographic region or even gender (Grown and Valodia, 2010). They can do this by imposing differential tax burdens on different groups and enabling a redistribution of wealth and income across society. As well as the potential tangible effects of redistributing wealth (and indirectly, economic and political power), differential tax burdens play a symbolic role in reflecting societal values about equity, solidarity and mutuality across society. In addition, as noted recently by Piketty (2014), the generation of accurate and public information about individual wealth that is required for the effective imposition of a wealth tax can help to shed light on how power is structured across society.

However, the democratic and socially progressive benefits of tax are not automatic and need to be accompanied by political action to ensure that tax is collected in ways that are considered fair and public revenue used appropriately and accountably. In the absence of effective forms of direct and representative democracy, taxes can equally be used as an instrument of appropriation and subjugation, as was often the case with imperial powers in their colonies (Fukuyama, 2012).

The potential for tax to catalyse the development of a democratic state can also be contingent on other means by which a state generates revenue. Where states are 
able to derive a greater amount of income independently of citizens or with relatively little organisational or political effort, a 'state-society disconnect' may occur (Moore, 2001, 2004). This is typically seen in countries with substantial natural resource wealth (notably oil, minerals and timber), which can give states access to 'unearned income' in the form of 'natural resource rents' (Cooper, 2002).

Such sources of income offer states greater opportunity to exercise power without the support or consent of citizens, who are in turn discouraged from bargaining with the state to ensure appropriate use of public revenue. Because natural resource rents require a relatively small bureaucratic apparatus, they are also associated with a general neglect of public administration. Natural wealth has thus been described as a 'resource curse' because of its association with corruption, conflict, war and human rights abuses (Collier, 2008).

\section{Revenue}

As already noted, tax is an important source of public revenue that can be used to finance health care and other public services that promote and protect health, including education, sanitation and public transport. According to the World Health Organization (2010b), increasing the efficiency of taxation and applying innovative financial mechanisms such as financial transaction taxes (FTT) are two important strategies for achieving universal health coverage. It also funds a range of political, juridical and economic institutions that are core to the functioning of societies.

States can also derive income from natural resource rents (as discussed earlier); charges applied to the provision of services (e.g. user fees) or access to privileges (e.g. licenses); profits made by state-owned companies and industries; returns on public investments; or loans or grants. However, generally speaking, tax revenues are the main source of government funds available for financing and expanding health care in most nations. In LMICs, they account for $\sim 65 \%$ of total government revenues (International Monetary Fund (IMF), 2011).

Standardised and consistent data on general public and tax revenue in LMICs are difficult to obtain due in part to different systems of government and tax accounting. Statistics are often incomplete and not comparable across countries. For example, while in most countries central government finance data have been consolidated into one account, in others, central government accounts exclude certain pools of public finance such as social security funds (World Bank, 2015). Similarly, the way data on central or federal government tax revenue and local or state are organised and managed can vary.

On average, both public revenue in general and, more specifically tax revenue, as a proportion of gross domestic product (GDP), are lower in poor countries compared to middle- and high-income countries. However, within these country groupings, there can be tremendous variation. For example, within Organisation for Economic Cooperation and Development (OECD) countries between 2006 
and 2010, the annual tax revenue ranged from $48.6 \%$ in Denmark to $26.2 \%$ in the United States (McQuaig and Brooks, 2013). And, as shown by Meheus and McIntyre (2016) in this issue, there is considerable variation in terms of government expenditure relative to GDP as well. For example, while government expenditure is $<14 \%$ of GDP in some LICs such as Sudan, Madagascar and Guinea-Bissau, it is over $50 \%$ in Lesotho and the Solomon Islands. Similarly, while it is $>55 \%$ of GDP in high-income countries such as Finland, Denmark and France, other high-income countries have relatively low levels of government expenditure, such as Singapore (14.5\% of GDP) and Hong Kong (19.3\% of GDP).

As a general rule, however, the proportion of GDP captured as tax revenue rises as countries become wealthier in terms of GDP (see Table 1). In addition, there is a general trend for the tax/GDP ratio to increase over time: among OECD countries, for example, this rose from 25 to $35 \%$ during the 49 yr between 1965 and 2014 (OECD 2015).

The relatively low tax-to-GDP ratio in LMICs means there is significant potential for generating additional revenues for health (Laffer, 2004). India is a prime example. In 2011 the government spent US\$18 per person on health, which is considerably less than the $\$ 86$ estimated to be required to fund essential and basic health care for all (McIntyre and Meheus, 2014). However, government budgets were constrained by the fact that tax revenue, as a percentage of GDP, was only $9 \%$ in 2011 (World Bank 2016). If tax revenue as a percentage of GDP were to be raised to allow the government to spend the equivalent of $5 \%$ of GDP on health, government per capita health expenditure would rise to US\$74 and approach the $\$ 86$ per capita target set by the Chatham House Working Group on Health Financing.

Quite apart from the potential for tax to expand health budgets, tax-based health care financing systems (including mandatory social health insurance) creates the conditions for cross-subsidisation and risk-pooling arrangements, as well as potential efficiency gains from stronger and more strategic purchasing power and the avoidance of transaction costs associated with multiple and fragmented risk pools (World Health Organization, 2000). To date, there has been relatively little data looking at whether different types of tax have a differential impact on health outcomes. However, a recent study of the association

Table 1. Average tax revenue as a proportion of GDP

\begin{tabular}{lc} 
Country category & Tax revenue as a \% of GDP \\
\hline Low-income countries & 13.0 \\
Low- and middle-income countries & 17.7 \\
Upper-middle-income countries & 20.7 \\
High-income countries/OECD countries & 35.4 \\
\hline
\end{tabular}

Source: House of Commons International Development Committee. Tax in Developing Countries: Increasing Resources for Development. Fourth Report of Session 2012-2013 (International Development Committee (IDC), 2012). 
between different types of tax and various health indicators suggests that tax regimes with a stronger emphasise on direct rather than indirect tax are associated with better health outcomes and higher levels of health spending (Reeves et al., 2015).

Indirect forms of tax can also be directly associated with health benefits, especially if ear-marked to support health and other forms of social spending (Gallagher and Porzecanski, 2009). In Thailand, an additional 2\% surcharge on alcohol and tobacco was used to fund a Health Promotion Fund, raising US\$5060 million a year (Srithamrongsawat et al., 2010). Hungary too levied taxes on unhealthy foods during the Great Recession, in order to help maintain health care expenditure at a time of diminished government revenues from other sources (Mytton et al, 2012). While taxes on tobacco, alcohol and unhealthy food can be ear-marked as revenue to support additional public spending on health, it is also argued that such taxes should be collected as general revenue that can then be allocated as appropriate by government as a whole.

However, the health benefits of tax revenue generation must be balanced against their potential negative impact on household income, with knock-on health effects. Tax simulation models from South Africa, for example, have found that while increased taxes on general income, consumption or both could help expand health coverage, poorly selected consumption taxes could reduce access to nutrition and health care for poorer households (McIntyre and Ataguba, 2012).

\section{Redistribution}

Tax systems, when designed to be socially progressive and redistributive, provide the basis for a fairer distribution of wealth and resources across society. As mentioned earlier, progressive tax systems also enable cross-subsidisation and risk-pooling within health systems, which enables them to achieve both efficiency and equity goals. Importantly, as economic growth projections show little prospect of eradicating absolute poverty globally, redistribution is seen as a vital and necessary requirement for development (Woodward, 2015).

There is some evidence that income inequality is a determinant of health and wellbeing in its own right (Wilkinson \& Pickett, 2010). This thesis has been given added impetus by some evidence suggesting that inequality can also act as a drag on economic performance (Herzer, 2012). The postulated mechanisms by which social and income inequality generate health impacts include those that are mediated through behavioural, psycho-social and cultural pathways, as well as through their impact on public policy formulation. However, the thesis is also contested and remains an important area of research (Avendano and Hessel, 2015).

Tax policies that facilitate redistribution and fairness within society are therefore increasingly viewed as being important and valid public health measures. It is important to note that the optimal level of income or social equality is undefined and would be contested. Achieving complete equality through tax-based 
redistribution is likely to be politically unfeasible and socially unacceptable, and may be economically damaging. Additionally, the health benefits of ever greater social equality may diminish: one meta-analysis of multi-level studies has suggested that while reducing the Gini coefficient of income distribution down to 30 may reduce excess deaths substantially, any further reduction has little additional effect (Kondo et al., 2009).

Generally speaking, direct forms of tax upon wealth and income are more progressive than indirect forms of tax such as value-added tax (VAT), partly because indirect forms of tax tend to be flat and do not discriminate between rich and poorer households. One way to avoid or minimise the regressivity of indirect forms of tax is to exempt VAT from essential goods that are health promoting whilst aiming sales taxes at luxury goods. Additionally, the direct taxation of wealth has a greater potential to enable redistribution than the direct taxation on income given secular trends in the relative distribution of capital and labour in economies worldwide (Pikkety, 2014).

It should be noted however that the progressivity of a country's tax collection system may only be instrumental in redistributing wealth if also accompanied by decisions to spend public tax revenue in ways that are progressive (Prasad, 2008). For example, while the USA's tax collection system is actually more progressive than most European states (Prasad and Deng, 2009), there is greater redistribution in European states due to the social welfare transfers achieved after public spending.

\section{Re-pricing}

The ability of taxes to alter the price of goods, services and behaviours provides a mechanism, not just for raising revenue, but also for discouraging the consumption of unhealthy substances, or inhibiting behaviours that may be unhealthy or harmful. The most obvious example of this form of benefit is the taxation of tobacco which reduces smoking levels by increasing the cost of cigarettes (Frieden and Bloomberg, 2007).

Although many countries already impose high taxes on tobacco, the World Health Organization (2010b) estimates that a $5-10 \%$ increase in the tobacco tax rate could further reduce the prevalence of smoking, whilst also generating an additional US\$1.4 billion in revenue in LICs and US\$5 billion in middleincome countries (MICs) per annum. This would result in the 'triple win' of reducing unhealthy behaviour, raising public revenue for health care, and reducing the need for expensive treatments in the future (World Health Organization, 2012).

A potential fourth win is that once a commodity has been marked with a 'sin-tax', subsequent public perception of the industry producing the commodity changes. For example, opposition to the introduction of tobacco taxes in the form of tobacco industry claims that the tobacco industry was important for 
economic wellbeing and job creation became less salient once the democratically mandated stigma of a 'sin-tax' had weakened the credibility of the tobacco industry.

With unhealthy diets having overtaken smoking as causes of premature death and disability in many countries, attention is now focussed on taxing foods high in fat, salt and sugar that are cheap, widely accessible and heavily marketed (World Health Organization, 2004; Slimani et al., 2009). In Mexico, for example, a sugar sweetened beverage tax, which came into effect in early 2014 raised prices by $16 \%$ and reduced consumption by $12 \%$ (Colchero, 2016). In Hungary, a complex health-oriented food tax has reportedly led to a $25-35 \%$ decrease in the consumption of taxed goods (European Competitiveness and Sustainable Industrial Policy Consortium, 2014).

Taxes can also be applied to inhibit behaviours that have an indirect negative impact on health. For example, levies can be applied in order to increase the cost of polluting behaviour and protect the environment from damage. This could include the stronger use of taxes to curb greenhouse gas emissions which would help mitigate climate change and encourage renewable energy development (Bird \& Zolt, 2003; Cobham, 2005a).

\section{Regulation}

Taxes can be used to shape individual behaviour by affecting the price and cost of certain commodities or behaviours. But they are also associated with the regulation of entire markets or economic sectors by virtue of the fact that applying a tax on a commodity or service requires some form of government regulation and administration to enable the tax to be collected. This may contribute towards strengthening regulation more generally in an economic sector that is currently under-regulated and harmful to health.

For example, as far back as 1980, the Brandt Report proposed a tax on the global arms trade as a way of establishing arms sales registers which would in turn increase transparency and help reduce conflict (Brandt, 1980). The illegal drugs (narcotics) trade is another example of an unregulated market that causes a great deal of harm through both the effects of drug addiction and poisoning and the effects of violence and corruption associated with failed attempts to eradicate the trade. Not only does this unregulated trade cause untold amounts of human suffering, it generates billions of dollars of untaxed profit every year which is used to corrupt governments and undermine democracy.

A third example of taxes that can enable socially useful regulation whilst generating public revenue is FTTs that can be designed to inhibit harmful speculative commodity and currency exchange, and generate billions of dollars of public revenue. It has been estimated that a US FTT could raise up to $\$ 175$ billion a year (Baker et al., 2009); while a FTT applied across the EU could bring in an estimated $£ 46$ billion a year (McQuaig and Brooks, 2013: 247). 


\section{Harnessing the potential of tax}

The preceding section describes how tax can promote health through five different pathways: (a) representation through more democratic, accountable and responsive government; (b) revenue generation for better financing of health systems; (c) redistribution of public wealth to reduce social inequalities; (d) re-pricing of goods and services to foster a healthier food environment and healthier consumption behaviours; and (e) regulation and control of the harmful and illicit economy.

However, the health benefits of tax are not necessarily easily achieved. In particular, for LMICs, a number of structural constraints would need to be overcome. In this section, we highlight what we believe are the key constraints that hinder LMICs from making use of tax as a health-promoting instrument.

One important constraint is the weak tax administrations of many countries which is a cause of substantial losses of public revenue (Moore, 2004). In Kenya, for example, arrears for tax payment defaults in 2005 were US\$1.32 billion and corresponded to about half the country's public revenues (Christian Aid, 2005). Estimates of non-compliance of VAT in some developing countries have been put at $50-60 \%$ compared with $7-13 \%$ in developed countries (OECD, 2000; IMF, 2011) and the failure to collect all property taxes due to deficiencies in the registration and valuation of properties is also relatively common (IMF, 2011).

The problems of weak tax administrations have been accentuated by the removal of import and export duties as part of prevailing trade liberalisation policies. These duties were amongst the easiest to administer and previously contributed significantly to revenue income in poor countries, in some cases 30 to $50 \%$ of total government revenue (Murphy, 2007). However, between 1995 and 2003, the share of customs revenues to total state revenues shrunk from an average of 22 to $16 \%$ in poor countries, and from 13 to $7 \%$ in MICs (Martens, 2007).

Such losses in revenue were supposed to have been compensated for by economic growth and increases in VAT revenue, but this has not always materialised. One study found that LICs were only able to compensate for about $30 \%$ of revenue losses caused by trade liberalisation (Baunsgaard and Keen, 2010), while other analyses have argued that the substitution of trade taxes with VAT has had negative welfare effects in countries with large informal economies (Emran and Stiglitz, 2005).

The relatively large 'informal' and illicit economy that operates beyond the ambit of tax collecting bodies is another structural constraint affecting many developing countries (Bird \& Zolt, 2003). In one study from 2003, the 'shadow economy' (the production of goods and services that are deliberately concealed to avoid tax, social security contributions and labour and safety standards) was found to have made up 41.2 and $41.5 \%$ of GDP in Africa and Latin America, respectively, compared with $16.8 \%$ in OECD countries (Schneider, 2004). 
In general, much larger sections of the population only contribute to public revenue indirectly through consumption taxes in poor countries compared with rich countries.

Economic globalisation and the greater mobility of finance and productive capacity have also resulted in many countries competing with each other for foreign direct investment (FDI) by offering low corporate tax rates, tax holidays, free repatriation of profits and establishing export processing zones (EPZs) where goods can be landed, handled and re-exported without the attention of customs authorities (Jauch, 2002; Goldman, 2006; Shaxson and O'Hagan, 2013). EPZs are also associated with absent or low labour standards, non-unionisation and low wages (Klein, 2001) which pose additional threats to health as well as to democracy and labour rights.

Losses in public revenue can also be traced to the rise in number and size of transnational corporations with complex legal structures and aggressive accounting practices intended to evade or avoid tax. These include 'transfer mispricing' and 'transfer misinvoicing' designed to shift profits from high to low tax jurisdictions, as well as other forms of aggressive tax avoidance based on arrangements for paying royalty fees and making loans between subsidiaries of the same company.

Tax evasion and avoidance, by individuals and trans-national corporations (TNCs), is linked to the international tolerance of tax havens: real or virtual jurisdictions that offer low or zero taxation and a secrecy regime sustained through laws and de facto judicial arrangements. Not only does this allow profits and wealth to be hidden away from tax authorities, banking secrecy enables the laundering of proceeds from a range of health-harming illegal activities such as drug, arms and human trafficking. The loss of tax revenues through illicit economic activities can amount to hundreds of billions of dollars every year (Cobham, 2005b). The African Union has previously estimated that $\$ 148$ billion a year (approximately a quarter of the continent's GDP) leaves the continent due to corruption (Jackson, 2006).

Because of the secrecy, the amount of revenue lost to tax havens is hard to determine. One estimate of illicit financial flows from developing countries between 2003 and 2012 amounted to \$6.6 trillion a year (Kar and Spanjers, 2014). Another study of 139 mainly LMICs estimated that as of 2010, between $\$ 21$ and $\$ 32$ trillion had been invested virtually tax-free through $>80$ offshore jurisdictions, of which \$7.3-\$9.3 trillion of this unrecorded offshore wealth was accounted for by individual private elites (Henry, 2012). These figures excluded non-financial wealth in the form of real estate, yachts, racehorses, gold bricks as well as the drain of human capital. Based on a conservative assumption of this wealth earning a return of $3 \%$ a year, it is estimated that up to $\$ 189$ billion per year of tax revenues was lost - more than twice the $\$ 86$ billion that OECD countries as a whole spend on overseas development assistance.

These inter-connected structural problems are clearly not just about tax policy, but embrace questions about effective democracy, the role and capacity of 
government (including law enforcement and judicial systems), the shape and form of economic globalisation and global governance. As such they highlight the point that the use of tax to improve health through the five Rs is not simple or straightforward.

\section{Conclusion}

This article describes how tax has the potential to address many pressing global health priorities including enduring poverty, widening social and health inequalities, under- resourced health systems and the unhealthy consumption of tobacco, sugar, alcohol and processed food. Ecological degradation and climate change, perhaps the ultimate threats to global health, can also be tackled through tax policy. Illicit trade in arms and narcotics, as well as the harmful speculative trading of currencies and food commodities can be curbed by tax instruments and regulation. Perhaps most importantly, tax policy provides a route by which better and more accountable government can be established.

The relationship between both public revenue in general and tax revenue specifically with GDP is critical, especially for poorer countries. McQuaig and Brooks (2013) have examined the association between the level of tax as a percentage of GDP and various social and health indicators, and have found patterns of correlation which support the thesis that tax can play an overall positive function in society. This would seem to reinforce other analyses suggesting a positive association between direct forms of tax upon citizens and democratic and accountable government, outlined earlier.

The potential for tax to be used as a positive and progressive public health instrument implies shifting away from a prevailing neoliberal orthodoxy that has tended to neglect the positive attributes of tax policy in favour of deregulation, privatisation and small government, towards a new political economy that places greater emphasis on public finance, democratic government, equity and public-interest regulation. In our view, the health community could help catalyse this shift. But action needs to occur at both the national and international level.

One action is for the global health community to help direct greater policy and public attention towards the simple fact that many LMICs have the capacity to capture a higher proportion of GDP as public revenue. Examples of countries that have enlarged their fiscal space include Indonesia which increased its tax revenues from 9.9 to $11.1 \%$ of GDP (excluding oil GDP) over a four-year period due to a simplification of the tax system (World Health Organization, 2010a) and Vietnam which increased its tax revenue to $28 \%$ of GDP over two decades (IMF, 2011).

A second action would be for public health advocates and organisations to call for more effective and efficient tax administrations (including better customs enforcement to detect and halt intentional misinvoicing of trade transactions), as well as tax regimes that are applied more to income and wealth rather than to 
consumption. While responding to the immediate demands of illness and disease, the health community can also encourage the democratic and legal functioning of public institutions as a vital public health intervention.

Conducting research on the relationship between tax policy and health would be a further important action. In particular, more research is needed to examine the potential impact of taxes on alcohol, sugary drinks and ultra-processed foods on individual consumption behaviour as well as revenue generation. The relative advantages and disadvantages of different types of tax regime in enabling efficient and equitable health financing arrangements could also be better studied. Research findings and recommendations should however be linked explicitly to policy reform efforts that take into account the specific political, social and economic conditions of individual countries.

At the international level, the global health community should also direct attention towards efforts to curb tax avoidance and evasion, as noted by a UN Committee of Experts on International Cooperation in Tax Matters which proposed a 'UN Code of Conduct on Cooperation in Combating International Tax Evasion and Avoidance' (2007). To date, efforts have mostly focussed on voluntary behaviour change. But in light of limited progress having been made, rules and regulations that are binding and enforceable are required. These should include agreements on the establishment of public registries of meaningful beneficial ownership information on all legal entities; the requirement for TNCs to provide full disclosure of all economic and financial transactions including their revenues, profits, losses, sales, taxes paid, subsidiaries and staff levels on a country-by-country basis; developing a new set of international accountancy standards that are removed from the control of the International Accounting Standards Board (a private corporation funded by the Big Four accountancy firms); and calling for an end to the secrecy regimes of banks and tax havens.

Developed countries also have an important responsibilities as noted by the High-Level Panel of Eminent Persons on the Post-2015 Development Agenda which called them to seize and return assets that may have been stolen, acquired corruptly or transferred abroad illegally from developing countries, and to do more to prevent illicit financial flows from developing countries.

Finally, the global health community are in a privileged position to call for taxes on 'global public bads', as a means of both preventing social harm and raising additional revenue for development finance. For example, the Technical Group on Innovative Financing Mechanisms (2004), derived from the 2004 Geneva Declaration, has noted the feasibility of a tax on heavy conventional weapon transactions which might help improve population health outcomes and strengthen health systems, and promote good government more generally. A regulatory approach towards the illicit drugs might also raise considerable public revenue whilst simultaneously reduce the burden of violence and harm caused by both narcotics and the war on drugs. 


\section{Acknowledgements}

The authors like to thank Aaron Reeves and Tomas Lievens for their helpful comments and suggestions as reviewers of the paper. The authors are also grateful to other colleagues who have provided important input for this manuscript.

\section{References}

Avendano, M. and P. Hessel (2015), 'The income inequality hypothesis rejected?', European Journal of Epidemiology, 30(8): 595-598.

Baker, D., R. Pollin, T. McArthur and M. Sherman (2009), 'The potential revenue from financial transactions taxes'. Massachusetts: Political Economy Research Institute Working Paper 212.

Baunsgaard, T. and M. Keen (2010), 'Tax revenue and (or?) trade liberalization', Journal of Public Economics, 94(9-10): 563-577.

Bird, R. M. and E. M. Zolt (2003), Introduction to tax policy design and development, Washington DC: World Bank.

Brandt, W. (1980), North-South: a programme for survival: report of the Independent Commission on International Development Issues, Massachusetts: MIT Press.

Bräutigam, D. (2008), 'Introduction: Taxation and State-Building in Developing Countries', in D. Brautigam, H. Fjeldstad and M. Moore (eds), Taxation and State-Building in Developing Countries: Capacity and Consent, 1st edn, Cambridge: Cambridge University Press, 1-33.

Christian Aid (2005), 'The shirts off their backs: how tax policies fleece the poor', Briefing Paper, September, 1-23. London: Christian Aid.

Cobham, A. (2005a), Taxation Policy and Development, Volume 2, Oxford: Oxford Council on Good Governance.

Cobham, A. (2005b), 'Tax evasion, tax avoidance and development finance.' QEH Working Paper Series 129, 1-20. Oxford: Queen Elizabeth House.

Colchero, M. A., B. M. Popkin, J. A. Rivera and S. W. Ng (2016), 'Beverage purchases from stores in Mexico under the excise tax on sugar sweetened beverages: observational study', British Medical Journal, 352: h6704.

Collier, P. (2008), The Bottom Billion: Why the Poorest Countries Are Failing and What Can Be Done About It, Oxford: Oxford University Press.

Committee of Experts on International Cooperation in Tax Matters (2007), The Proposed UN Code of Conduct on Cooperation in Combating International Tax Evasion and Avoidance, Geneva: Committee of Experts on International Cooperation in Tax Matters.

Cooper, F. (2002), Africa Since 1940: The Past of the Present, Cambridge: Cambridge University Press.

Emran, M. S. and J. E. Stiglitz (2005), 'On selective indirect tax reform in developing countries', Journal of Public Economics, 89(4): 599-623.

European Competitiveness and Sustainable Industrial Policy Consortium (2014), Food Taxes and Their Impact on Competitiveness in the Agri-Food Sector, Rotterdam: European Competitiveness and Sustainable Industrial Policy Consortium.

Frieden, T. R. and M. R. Bloomberg (2007), 'How to prevent 100 million deaths from tobacco', Lancet, 369(9574): 1758-1761.

Fukuyama, F. (2012), The Origins of Political Order, London: Profile Books. 
Gallagher, K. P. and R. Porzecanski (2009), China and Latin America Commodities Boom: a critical assessment, University of Massachusetts: Political Economy Research Institute.

Goldman, I. (2006), 'Tax justice briefing: tax competition', London: Tax Justice Network.

Grown, C. and I. Valodia (2010), 'Taxation and gender equity: an eight-country study of the gendered impact of direct and indirect taxes', University of KwaZulu-Natal: Population Studies \& Development Studies.

Henry, J. S. (2012), 'The price of offshore revisited'. London: Tax Justice Network.

Herzer, D. (2012), 'How does foreign direct investment really affect developing countries' growth?', Review of International Economics, 20(2): 396-414.

International Development Committee (IDC) (2012), Tax in Developing Countries: Increasing Resources for Development, London: IDC.

International Monetary Fund (IMF) (2011), Revenue Mobilization in Developing Countries, Washington, DC: IMF.

Jackson, P. (2006), 'The other side of the coin: the UK and corruption in Africa'. Report by the Africa All Parliamentary Working Group.

Jauch, H. (2002), 'Export processing zones and the quest for sustainable development: a Southern African perspective', Environment and Urbanization, 14(1): 101-113.

Kar, D. and J. Spanjers (2014), Illicit Financial Flows from Developing Countries: 2003-2012, Washington DC: Global Financial Integrity.

Klein, N. (2001), No Logo: Taking Aim at the Brand Bullies, London: Picador.

Kondo, N., G. Sembajwe, I. Kawachi, R. M. van Dam, S. V. Subramanian and Z. Yamagata (2009), 'Income inequality, mortality, and self rated health: meta-analysis of multilevel studies', British Medical Journal, 339(7731): 1178-1181.

Laffer, A. B. (2004), 'The laffer curve: past, present, and future', The Heritage Foundation, www.heritage.org/research/taxes/bg1765.cfm [21 October 2016].

Martens, J. (2007), The Precarious State of Public Finance, London: Tax Justice Network.

McIntyre, D. and J. E. Ataguba (2012), 'Modelling the affordability and distributional implications of future health care financing options in South Africa', Health Policy and Planning, 27(Suppl 1): i101-i112.

McIntyre, D. and F. Meheus (2014), 'Fiscal space for domestic funding of health and other social services', Centre on Global Health Security Working Group Papers 44, 0-45. London: Chatham House.

McQuaig, L. and N. Brooks (2013), The Trouble with Billionaires, London: Oneworld Publications.

Meheus, F. and D. McIntyre (2017), Fiscal space for domestic funding of health and other social services. Health Economics, Policy and Law, 12(2): 159-177.

Moore, M. (2001), 'Political underdevelopment: what causes 'bad governance.", Public Management Review, 3(3): 385-418.

Moore, M. (2004), 'Revenues, state formation, and the quality of governance in developing countries', International Political Science Review, 25(3): 297-319.

Moore, M. (2007), How Does Taxation Affect the Quality of Governance? Volume 280 Sussex: Institute of Development Studies.

Murphy, R. (2007), Closing the Floodgates: Collecting Tax to Pay for Development, London: Tax Justice Network.

Mytton, O. T., D. Clarke and M. Rayner (2012), 'Taxing unhealthy food and drinks to improve health', British Medical Journal, 344: e2931. 
Organisation for Economic Cooperation and Development (OECD) (2000), 'Towards global tax co-operation', Report to the 2000 Ministerial Council Meeting and Recommendations by the Committee on Fiscal Affairs, Paris.

OECD (2015), 'Tax policy - revenue statistics', http://oecd.org/tax/tax-policy/revenue-statisticsratio-change-latest-years.htm [28 December 2015].

Pikkety, T. (2014), Capital in the Twenty-First Century, Boston, MA: Harvard University Press.

Prasad, M. and Y. Deng (2009), 'Taxation and the worlds of welfare', Socio-Economic Review, 7(3): 431-457.

Prasad, N. (2008), 'Policies for redistribution: the use of taxes and social transfers', International Institute for Labour Studies, Discussion Paper Series. Geneva: International Labour Organisation. http://www.oit.org/wcmsp5/groups/public/—dgreports/-inst/ documents/publication/wcms_193159.pdf.

Prichard, W. (2010), "Taxation and state building: towards a governance focused tax reform agenda." Working Paper 341, Sussex: Institute of Development Studies. https:/doi.org/ :9781858649269 [21 October 2016].

Reeves, A., Y. Gourtsoyannis, S. Basu, D. McCoy, M. McKee and D. Stuckler (2015), 'Financing Universal Health Coverage - effects of alternative tax structures on public health systems: cross-national modelling in 89 low-income and middle-income countries', The Lancet, 6736(15): 1-7.

Schneider, F. (2004), 'The size of the shadow economies of 145 countries all over the world: first results over the period 1999 to 2003', Bonn: Institute for the Study of Labor Working Paper.

Shaxson, N. and E. M. O’Hagan (2013), A Competitive Tax System Is a Better Tax System, London: New Economics Foundation.

Slimani, N., G. Deharveng, D. A. T. Southgate, C. Biessy, V. Chajès, M. M. E. van Bakel, M. C. Boutron-Ruault, et al. (2009), 'Contribution of highly industrially processed foods to the nutrient intakes and patterns of middle-aged populations in the European prospective investigation into cancer and nutrition study', European Journal of Clinical Nutrition, 63(Suppl 4): S206-S225.

Srithamrongsawat, S., W. Aekplakorn, P. Jongudomsuk, J. Thammatach-aree, W. Patcharanarumol and W. Swasdiworn (2010), 'Funding health promotion and prevention - the thai experience', World Health Report - Background Paper 45, 1-10. Geneva: World Health Organisation.

Technical Group on Innovative Financing Mechanisms (TGIFM) (2004), 'Action against hunger and poverty', Report of the technical group on innovative financing mechanisms by Brazil, Chile, France and Spain for the Summit Conference, New York.

Wilkinson, R. and K. Pickett (2010), The Spirit Level: Why Equality If Better for Everyone, 3rd edn, London: Penguin Books.

Woodward, D. (2015), 'Incrementum ad absurdum: global growth, inequality and poverty eradication in a carbon-constrained world', World Economic Review, 4: 43-62.

World Bank (2015), 'Tax revenue (\% of GDP)', World DataBank, http://databank.worldbank. org/data/views/reports/metadataview.aspx [21 October 2016].

World Health Organization (2000), World Health Report - Health Systems Improving: Performance, Geneva: World Health Organization. http://www.who.int/whr/2000/en/ whr00_en.pdf [21 October 2016].

World Health Organization (2004), Global Strategy on Diet, Physical Activity and Health, Geneva: World Health Organization. 
194 D A VID M C C O Y ETAL.

World Health Organization (2010a), World Health Report 2010 - Health Systems Financing: The Path to Universal Coverage, Geneva: World Health Organization.

World Health Organization (2010b), More Money for Health', in WHO (ed.), The World Health Report - Health Systems Financing: The Path to Universal Coverage, Geneva: WHO.

World Health Organization (2012), Tobacco Taxation and Innovative Health-Care Financing, New Delhi: World Health Organization. 